\title{
2 SEGMENTS OF COGNITIVE RESPONSES TOWARDS LOCAL FOOD SAFETY CONCERNS AMONGST INTERNATIONAL STUDENTS IN GHANA
}

\author{
Abednego Kofi Bansah ${ }^{1}$, Issahaku Adam ${ }^{1,2}$, Stephen Edem Hiamey ${ }^{l}$
}

\begin{abstract}
Despite the attention paid to food safety research, few empirical works have used a non-reductionist perspective to understand how international consumers cognitively respond to local food safety conditions. Using the tri-component theorisation and the two-step clustering approach with the Kruskal Wallis test on a sample of 109 international students in Ghana, this study provides a nonreductionist cognitive segment of international students towards local food safety conditions in Ghana. The findings revealed that there are three cognitive segments of international consumers towards local food safety conditions, namely self-regards, pessimists, and epicureans. Self-assureds respond to their own self-cognition towards local food safety concerns but deny the cognition of others, moderately respond affectively and sometimes avoid local foods. Pessimists have a highly sensitive cognitive response towards local food safety conditions, high affective responses and avoid the consumption of local foods as a result, while epicureans do not cognitively respond to local food safety conditions, have low affective reactions and consume local foods regardless of the food safety conditions. The implications of these findings in the context of local food preparation, packaging, and handling as well as food safety regulations and marketing are discussed.
\end{abstract}

Keywords: clustering, cognition, conative response, food behaviour, food safety,

\section{INTRODUCTION}

Food safety issues have been a major problem for both developed and developing nations (Osaili et al., 2018; Smigic et al., 2016). Foodborne diseases due to inadequate food safety measures constitute a threat to global public health (Adesokan et al., 2015). A case in point is SARS-CoV-2 where an initial assessment linked the virus to a food market (Ceylan et al., 2020). The World Health Organization (WHO, 2017) estimates that about 600 million people worldwide every year fall ill after eating contaminated food. Of this number, about 420,000 die (WHO, 2017). Nardi et al. (2020, p. 2) define food safety as the presence of physical, chemical, or biological contaminants that are unexpected or unidentified on the product label. Unvaryingly, consumers have become conscious of the dire consequences of foodborne diseases associated with food safety conditions. This consciousness has resulted in the mental processing of every food safety situation especially within the context of foreign foods where the food ingredients, methods of preparation, and handling are unfamiliar to the consumer.

Though all consumers react to food safety concerns, international food consumers react with higher concern levels and scepticism since everything about the food is new, coupled with the uncertainty over the consequences of contracting any food-related illness (Adam et al., 2014; Amuquandoh \& Asafo-Adjei, 2013). International food consumers engage in cognitive evaluation of every food safety situation due to their

1. Department of Hospitality and Tourism Management, University of Cape Coast, Cape Coast Ghana. Email: abednego.bansah@ucc.edu.gh, issahaku.adam@ucc.edu.gh, stephen.hiamey@ucc.edu.gh

2. School of Tourism and Hospitality" University of Johannesburg, South Africa 
unfamiliarity with such situations to ascertain whether the conditions are dire or otherwise, which ultimately triggers a certain behavioural response (Amuquandoh \& Asafo-Adjei, 2013; Cortese et al., 2016). Through this psychological processing of food safety situations, international food consumers react to local food safety conditions in varied ways, including stopping purchases of local foods entirely, avoidance of specific local food products, rejection of specific local food products, and paying more for foods known to have been sourced from safe sources, especially those they are familiar with, in their home countries (Brewer \& Rojas, 2008; Hassan \& Dimassi, 2014; Vainio et al., 2020). International consumers' behaviours towards local foods are actions taken based on their cognitive and affective responses carved within the context of prevailing external environmental factors such as personal relation, cultural exigencies, contingencies, etc. (Perner, 2018). Therefore, favourable cognitive and affective evaluations of local food safety conditions, as encountered in international destinations, inform their local food consumption behaviour (Sahney, 2018).

Despite past research interests in food safety situations, most of such studies (Cortese et al., 2016; Hassan \& Dimassi, 2014; Hiamey \& Hiamey, 2018; Omari et al., 2018). have focused on only the behavioural reactions of consumers towards food safety concerns without recourse to their socio-psychological evaluations, especially cognitive, affective, and conative responses towards food safety conditions. The focus of past studies on the sensory reactions towards food safety concerns has limited our understanding of the sociopsychological processes that consumers consider in reacting to local food safety conditions, especially in relation to foreign dishes. However, evidence from consumer psychology (Chih et al., 2015; Chowdhury \& Salam, 2015; Mullan et al., 2013) indicates that to better address consumer needs and behaviour towards local food safety conditions, there is the need to gain an understanding of their socio-psychological decisionmaking processes including their cognitive and conative responses to such situations and not just their sensory behavioural reactions. In specific contexts to international students, little effort has been focused on understanding their socio-psychological reactions towards local food safety conditions. More so, previous studies on international students' food-related issues did not touch on their socio-psychological evaluation of food safety and how that could impact their behaviour towards local foods of their host countries (Alakaam \& Mayfield-Johnson, 2015; Almohanna et al., 2015; Corcoran, 2018). Therefore, there is a dearth of knowledge on the cognitive and conative evaluations of international students' food safety concerns over local food safety conditions. Consequently, the objectives of this study are to (a) explore the cognitive-affective and conative responses of international students towards local food safety conditions, (b) segment international students based on their cognitive, affective, and conative responses towards local food safety conditions and (c) profile international students' socio-psychological segments across their background characteristics. Aside from contributing to the food safety literature, an understanding of how international students cognitively and conatively respond to local food safety concerns will help individual countries and management of universities to properly target their advisory and marketing information to prospective international students. It will also help those involved in the local food service business to become aware of the food safety requirements of international students and take steps to improve upon them. 


\section{LITERATURE REVIEW}

\section{Local/Traditional Foods}

The definition of local food is idiosyncratic and not universal (Eriksen, 2013). It could be defined from both the demand and supply sides. From the demand side, Guerrero et al. (2009) define local food as:

"A product frequently consumed or associated with specific celebrations and/or seasons, normally transmitted from one generation to another, made accurately in a specific way according to the gastronomic heritage, with little or no processing/manipulation, distinguished and known because of its sensory properties and associated with a certain local area, region, or country" ( $p$. 348).

From the supply side, Nummedal and Hall (2006) state that local food is any food associated with a specific geographical area or local specialty that has a local identity. This supply-side definition is in line with Penney and Prior (2014), who notes that local food is food produced, processed, traded, and sold within a defined geographic radius, often 30 miles. Traditional foods can be termed as eating habits, naturalness, heritage, taste, and locality (Guerrero et al., 2016). Habit-natural, origin locality, processing-elaboration, and sensory properties are four main dimensions identified for the concept of traditional food products (Guerrero et al., 2009). Traditional foods could also be characterised in terms of specific sensory attributes, gastronomic heritages, eating habits, and association with certain local areas (Verbeke et al., 2016). Therefore, both terms are used interchangeably since each definition culminates into food consumption within a stated geographical area.

The role of traditional foods (TFs) on society cannot be overstated (Skalkos et al., 2021) due to their various natural nutritional composition (Du Plooy et al.,
2018; Rahman et al., 2021; Yulia et al., 2018), promotion of destination attractiveness, and support for local agro-economies (Hsu et al., 2018). While the popularity of traditional foods continues to intrigue people of diverse backgrounds (Braziotis et al., 2013), there are generalised concerns among consumers about the integrity and quality of the foods (Wu et al., 2015). The origin and authenticity make traditional foods incredibly important (Serrano-Cruz et al., 2018). As such, consumers' interest in environmentally friendly production, respect for animal welfare, and the origin of products and authenticity as quality enhancers are vital (Doherty et al., 2015). While many studies have been conducted on traditional foods in relation to consumers' characteristics and perceptions of their purchases (Cacciolatti et al., 2015), new technologies and innovations (Guerrero et al., 2016), health (Tanuwidjaja et al., 2016), and territorial context (Stolzenbach et al., 2013), issues related to food risk remains a concern when it comes to traditional foods in developing countries (Hidalgo-Milpa et al., 2016; Hovsepyan et al., 2016). Within the West African context, the preparational conditions of traditional foods remain questionable, with little or no official control for their compliance to national regulatory standards (Adeyeye, 2016).

\section{Local Food Safety Concerns}

Nardi et al. (2020, p. 2) define food safety as the presence of physical, chemical, or biological contaminants that are unexpected or unidentified on the product label. These biological, chemical and physical contaminants find their way into ready-to-eat or prepared-to-eat foods through improper handling either at home or within foodservice establishments (Ovca et al., 2014). Between 10-20\% of FBD outbreaks are due to poor handling practices (Girma \& Hanley, 2015). 
Specifically, about $75 \%$ of all FBD outbreaks in food service establishments are due to poor food handling practices (Gizaw et al., 2014; Okonko et al., 2009). Unvaryingly, consumers have become conscious of the dire consequences of FBD. In Ghana, several studies confirm that urban consumers are concerned about food safety issues (Hiamey \& Hiamey, 2018; Omari \& Frempong, 2016; Omari et al., 2018). The concerns were in the areas of biological, chemical, and physical contamination of food and vendor-related concerns.

Although interest in how consumers react to food safety issues is paramount, a specific interest in higher education students is limited. These higher education students could be responsible for households in the future and if they are not properly informed, they could put their dependants at risk of foodborne illnesses (Byrd-Bredbenner et al., 2008; Luo et al., 2019). Several studies conclude that adolescents and children get their first source of information on food safety concepts from their parents (Byrd-Bredbenner et al., 2010; Coulson, 2002; Eves et al., 2006). However, as they grow, they become independent of their parents and tend to make their own decisions (Caraher et al., 2004). Higher education students fall into this category. Empirical studies conclude that there is low food safety knowledge among young adults (Giritlioglu et al., 2011; Osaili et al., 2011). Specifically, among college students, some studies conclude that they do not have adequate knowledge on food safety (Byrd-Bredbenner et al., 2007; Ferk et al., 2016; Green \& Knechtges, 2015; Hassan \& Dimassi, 2014; Lazou et al., 2012; Sanlier \& Konaklioglu, 2012; Stratev et al., 2017).

There is some division among researchers, however, on whether knowledge leads to actual behaviour (Wardle et al., 2002). One strand of evidence points in the direction of knowledge leading to behaviour (Abbot et al., 2009). Some studies conducted in higher education environments suggest that consumers with high education do avoid places with food safety concerns (Adam et al., 2014; Liu \& Niyongira, 2017). The other strand of literature reports that knowledge does not lead to actual behaviour (Clayton et al., 2003; Harris \& Mullan, 2009; Soon et al., 2012). For instance, a study on food handling behaviour among middle school children in the USA found that although they had a fair knowledge of food safety, which did not translate into behaviour (ByrdBredbenner et al., 2010). This could be attributable to the fact that people perform some behaviour if they think it is essential (Ovca et al., 2014). About gender differences, Mullan et al. (2013) found that there are no differences in food safety behaviour. However other socio-demographic characterisations such as vulnerability have predicted food safety behaviour. For example, Milazzo et al. (2017) found that disadvantaged people consumed more high-risk foods than their advantaged counterparts. Consequently, risk perception is a principal factor that influences behaviour (Mullan et al., 2013; Vainio et al., 2020), which most of these young adults, including college students, do not necessarily care, thus, leading to a major public health concern (Hertzman et al., 2011).

\section{Local Foods}

The sustainability of food traditions for its development and utilization is very much dependant on food knowledge (Ohiokpehai, 2003). As such, the role of traditional food knowledge as a cultural identity in terms of specific food traditions and practices cannot be overstated (Sharif et al., 2016, p. 569). A study conducted on consumers' attitudes and perception of traditional foods revealed that participants who know the regional traditional foods well continue to choose them due to several reasons, which include being local 
products with local raw materials, the nutritional properties, the social impact, to mention a few (Skalkos et al., 2021). The literature indicates that total perception or overall image of a product is measured by consideration of all the knowledge, impressions, prejudices, and emotional thoughts that individuals have about a particular product (Mgonja et al., 2017, p. 799).

A systematic review of literature on local food from the consumer's perspective revealed that the origin of foodstuffs used to produce local food as well as the influence of personal and social norms plays a significant role in the formation of attitudes towards local food (Feldmann \& Hamm, 2015). An individual's overall perception of local foods is evaluated based on cognitive/perceptual and affective factors, and these two interdependent psychological constructs, when taken together, play a key role in an individual's understanding. According to Mogonja et al. (2017), while cognitive/perceptual evaluations of an individual result from accumulated knowledge and beliefs about the local foods that influence the way individuals perceive these local foods, the affective evaluations (feelings) about the local foods significantly influence individuals' overall perceptions about the local foods. It is suggested that food consumption and characteristics of individuals in relation to human eating behaviour, which is influenced by cues from foods, the body, and the social and physical environment, is affected by and associated with individuals' feelings (Desmet \& Schifferstein, 2008). Consequently, negative perceptions about local food as a result of the food safety issues will result in a negative attitude towards it. But this is also moderated by the characteristics of the purchaser since there is the potential for different interpretations of the food safety issues by different people. A case in point is international students involved in this study.

\section{Purchasing Behaviour}

Consumers react to food safety concerns in several ways, including stopping purchases, avoidance of specific products, rejection of specific products, and paying more for food known to have been sourced from safe sources (Brewer \& Rojas, 2008; Vainio et al., 2020). Consumers' behaviour intention or actual behaviour is the action taken concerning a product, which results from their affective (feelings/emotions) reaction in addition to other external environmental factors such as personal relation, cultural, exigences, contingencies, among others. (Perner, 2018). Therefore, a favourable affective reaction towards a product because of the belief (Sheth \& Mittal, 2004) will affect their purchase behaviour or intentions (Sahney, 2018). There is a limited number of studies on how higher education students' purchase behaviour relates to their food safety concerns (Cheng et al., 2017; Luo et al., 2019).

Food safety concerns among students mostly lead to two dichotomous purchase behaviours, that is, either it affects current purchase behaviour, or it does not. For example, Sun et al. (2014) found among college students in China that food safety concerns were high (about 95\%); however, 77\% purchased unsafe food. Ping et al. (2016) also report that although there is a high incidence of eating out among college students, most of them had unhealthy behaviour when eating out. On the contrary, a study conducted among college students in Italy found among other factors that food quality concerns were a principal factor when it comes to the choice of eating place (Savelli et al., 2017). A similar study by Adam et al. (2014) in Ghana also found that food safety concerns affect students' choice of eating place. This gives some insight into the behaviour of students when they must react to perceived food safety concerns. 


\section{Theoretical Framework}

The tri-component socio-psychological approach to analysing people's responses to attitudinal referents is used as the guiding framework for this study. The model explains how different external stimuli interactively inform the socio-psychological processes of informing behaviour. In this regard, the model postulates that there are three components of sociopsychological processes, namely cognition, affective, and conative (Maio \& Haddock, 2009). The cognitive component encapsulates the beliefs, thoughts, opinions, and knowledge about an object and individual possesses on a referent. These beliefs or knowledge are acquired through direct experience with the referent as well as information available on it.

The affective component measures the feelings one possesses towards the referent and reflects the emotions that one has on the object based on his/her cognitive evaluations (Schiffman \& Kanuk, 2004). These two innate and concealed aspects of the sociopsychological processes (cognitive and affective evaluations) inform the overt reaction that is exhibited towards a referent (Maio \& Haddock, 2009; Schiffman \& Kanuk, 2004). The conative component is the consumer's tendency to act towards a particular product or brand. In some interpretations, conation may refer to the behaviour itself (Schiffman \& Kanuk, 2004). On the converse, Assael (2004) is of the view that sometimes beliefs and evaluations of a particular product do not have to change for consumers to establish an intention to buy particularly if the economic inducement is large enough, for example, a sharp reduction in price. Therefore, within the context of this study, we argue that international students' concern towards local food safety concerns constitute a socio-psychological process such that it is primarily hinged on their cognitive responses which involve mental processing of the local food safety conditions they encounter. This cognitive evaluation of the local food safety conditions then informs the emotions/feelings they develop towards that local food, which in turn influences their behaviour towards local foods (Ha et al., 2018; Perez-Villarreal et al., 2019). The tri-component socio-psychological approach has been successfully employed to measure consumer attitude in a developing country, which revealed that consumer beliefs, feelings, and intentions to purchase are key factors that influence the decisions of consumers (Makanyeza, 2014).

\section{METHODOLOGY}

\section{Study Setting}

The target population for this study was all international students studying at the University of Cape Coast, Ghana as of November 2019. The University is in the city of Cape Coast in the Central Region of Ghana. The total student population at the time of data collection was 22,748 comprising of 13,252 males and 9496 females. Of this, there were 191 international students comprising 121 males and 70 females, from other African countries and the US. Originally established in 1962 with the faculty of education, the University has expanded to offer a myriad of programmes in Arts and Humanities, Social Sciences, Physical Sciences, Biological Sciences, Law, Medicine, Public Health, and Business. The University has several halls of residence fitted with several eateries ranging from traditional food vendors who either prepare the food at home or prepare it within the premises of the halls to conventional restaurants with highly structured menus and formalised eating environments. Additionally, there are also avenues for food hawkers to prepare and sell food at certain vantage points or prepare the foods at their homes and sell them on campus. 


\section{Survey Instrument}

A questionnaire made up of two sections was used to collect data from the respondents. The first section of the questionnaire was on demographic data. Following, 19 items were used to measure the cognitive, conative, and behavioural responses of the respondents towards local food safety concerns (Amuquandoh \& Asafo-Adjei, 2013). Respondents' cognitive responses were measured with six indicator items, seven for conative items, and six for behavioural responses as captured in Table 1. All the indicator variables were measured on a four-point Likert scale $(1=$ strongly disagree, 4 = strongly agree) (Bansah et al., 2018). A Cronbach's alpha of 0.796 was obtained from a pilot study conducted among 15 foreign tourists in the Cape Coast municipality.

Table 1: Operational Definitions for Latent Variables of the Study and Measured Items

\begin{tabular}{|c|c|c|c|c|}
\hline Latent Variable & $\begin{array}{l}\text { Cronbach's } \\
\text { alpha }\end{array}$ & $\begin{array}{l}\text { Operational } \\
\text { Definition }\end{array}$ & & Measured items \\
\hline \multirow[t]{6}{*}{$\begin{array}{l}\text { Cognitive } \\
\text { Responses }\end{array}$} & \multirow[t]{6}{*}{0.721} & \multirow{6}{*}{$\begin{array}{l}\text { Beliefs, } \\
\text { thoughts and } \\
\text { attributes that } \\
\text { are linked with } \\
\text { an object. }\end{array}$} & COG01 & $\begin{array}{l}\text { Unfamiliar table manners discourage me from } \\
\text { eating local foods. }\end{array}$ \\
\hline & & & COG02 & $\begin{array}{l}\text { Cooking utensils used in the preparation of food } \\
\text { discourage me from eating Ghanaian foods. }\end{array}$ \\
\hline & & & COG03 & $\begin{array}{l}\text { Advice by my health specialist has made me stay } \\
\text { away from local foods }\end{array}$ \\
\hline & & & COG04 & $\begin{array}{l}\text { The stories and the experiences of friends and } \\
\text { relatives discourage me from local foods. }\end{array}$ \\
\hline & & & COG05 & $\begin{array}{l}\text { Difficulty in ordering local dishes discourage me } \\
\text { from taking Ghanaian food. }\end{array}$ \\
\hline & & & COG06 & $\begin{array}{l}\text { Lack of competence in the local language } \\
\text { discourage me from local food. }\end{array}$ \\
\hline \multirow{7}{*}{$\begin{array}{l}\text { Affective } \\
\text { Responses }\end{array}$} & \multirow[t]{7}{*}{0.723} & \multirow{7}{*}{$\begin{array}{l}\text { Feelings that } \\
\text { are aroused in } \\
\text { response to an } \\
\text { attitude object. }\end{array}$} & AFF01 & Fear of illness deters from eating local foods. \\
\hline & & & AFF02 & $\begin{array}{l}\text { Suspicion of chemical present in the food } \\
\text { discourage me from eating local foods. }\end{array}$ \\
\hline & & & AFF03 & $\begin{array}{l}\text { The use of hands in food preparation discourages } \\
\text { me from eating local foods. }\end{array}$ \\
\hline & & & AFF04 & $\begin{array}{l}\text { The use of shared dishes deterred me from eating } \\
\text { local foods. }\end{array}$ \\
\hline & & & AFF05 & $\begin{array}{l}\text { The use of unfamiliar ingredients in food } \\
\text { preparation discourages me from eating local } \\
\text { foods. }\end{array}$ \\
\hline & & & AFF06 & $\begin{array}{l}\text { Fear of being served with unknown meat which is } \\
\text { culturally unacceptable discourage me from eating } \\
\text { Ghanaian foods. }\end{array}$ \\
\hline & & & AFF07 & I am repulsed by the way food is consumed locally. \\
\hline \multirow[t]{6}{*}{$\begin{array}{l}\text { Conative } \\
\text { Responses }\end{array}$} & \multirow[t]{6}{*}{0.740} & \multirow{6}{*}{$\begin{array}{lr}\text { Respond in a } \\
\text { certain manner } \\
\text { toward } & \text { an } \\
\text { object } & \text { or } \\
\text { activity. } & \end{array}$} & CON01 & $\begin{array}{l}\text { Too much litter around eating places deter me from } \\
\text { local foods. }\end{array}$ \\
\hline & & & CON02 & $\begin{array}{l}\text { Heaps of unwashed plates discourage me from } \\
\text { eating local foods. }\end{array}$ \\
\hline & & & CON03 & $\begin{array}{l}\text { The unpleasant display of food prevents me from } \\
\text { eating local foods. }\end{array}$ \\
\hline & & & CON04 & $\begin{array}{l}\text { Uncovered food and bottles discourage me from } \\
\text { eating local foods. }\end{array}$ \\
\hline & & & CON05 & $\begin{array}{l}\text { The presence of flies and other insects deter me } \\
\text { from eating local foods. }\end{array}$ \\
\hline & & & CON06 & $\begin{array}{l}\text { I avoid local foods because of my uncertainty } \\
\text { about their nutritious value. }\end{array}$ \\
\hline
\end{tabular}




\section{Data Collection and Procedure}

The target population for the study included all international students studying at the University of Cape Coast, Ghana as at the time of the data collection in December 2019. Two activities were undertaken prior to data collection. First, approval was sought from the Institutional Review Board at the University. Second, the Centre for International Education (CIE) keeps records of all international students and as such, permission was also sought from the Centre to make the research survey link available on the international students' list for data collection.

The link to the questionnaire was situated at Google forms websites. Upon approval from both IRB and CIE, the research survey link was made available to the international students. Owing to the small population size of the target population (191), coupled with the quantitative orientation of the study, a census was conducted for all the international students. Therefore, the link was sent to the emails of all international students two weeks before the completion of the first semester, meaning, students might have spent at least 14 weeks within the campus environment and region as a whole and therefore familiar with the food the local food environment. Overall, 109 completed questionnaires were filled out and retained for analysis. The preliminary analysis (Table 2) shows that the latent variables have high internal consistency as they recorded Cronbach Alpha scores higher than the 0.70 threshold (Cronbach, 1951).

Table 2: Descriptive Statistics on Measurement Items

\begin{tabular}{lllll}
\hline Item & \multicolumn{2}{l}{$\%$} & $\mathrm{~A}$ & $\mathrm{SA}$ \\
\cline { 2 - 5 } & $\mathrm{SD}$ & $\mathrm{D}$ & & \\
\hline Cognitive response $(\alpha=0.721)$ & 4.6 & 27.5 & 44.0 & 23.9 \\
COG01 & 1.8 & 22.0 & 45.0 & 31.2 \\
COG02 & 14.7 & 43.1 & 21.1 & 21.1 \\
COG03 & 11.0 & 40.4 & 28.4 & 20.2 \\
COG04 & 2.8 & 31.2 & 45.0 & 21.1 \\
COG05 & 6.4 & 33.0 & 45.0 & 15.6 \\
COG06 & & & & \\
Affective response $(\alpha=0.723)$ & 3.7 & 31.2 & 39.4 & 25.7 \\
AFF01 & 4.6 & 37.6 & 23.9 & 33.9 \\
AFF02 & 2.8 & 21.1 & 48.6 & 27.5 \\
AFF03 & 0.0 & 19.3 & 56.0 & 24.8 \\
AFF04 & 2.8 & 20.2 & 48.6 & 28.4 \\
AFF05 & 4.6 & 16.5 & 52.3 & 26.6 \\
AFF06 & 3.7 & 22.0 & 52.3 & 22.0 \\
AFF07 & & & & \\
Conative response $(\alpha=0.740)$ & 2.8 & 11.0 & 51.4 & 34.9 \\
CON01 & 0.0 & 18.3 & 40.4 & 41.3 \\
CON02 & 0.9 & 15.6 & 48.6 & 34.9 \\
CON03 & 1.8 & 9.2 & 43.1 & 45.9 \\
CON04 & 0.0 & 9.2 & 40.4 & 50.5 \\
CON05 & 11.9 & 48.6 & 19.3 & 20.2 \\
CON06 & & & & \\
\hline
\end{tabular}




\section{Data Analyses}

Three statistical tools were used to analyse the data, namely the two-step cluster technique, Kruskal Wallis rank sum test, and the Chi-square test of independence. The two-step clustering technique was used to segment the respondents based on the six items used to measure their cognitive responses towards food safety concerns. Since cognition serves as the foundation of attitudinal responses towards food safety concerns and informs and triggers other psychological and behavioural responses (Chowdhury \& Salam, 2015), it is used as the segmentation basis. Specifically, the two-step cluster analysis technique with the loglikelihood distance measure using the Schwarz Bayesian Criterion (BIC) was used in IBM SPSS Statistics version 24. The choice of the two-step clustering approach was based on three reasons. First, it is suitable for the clustering of both continuous and categorical data and, therefore, was considered ideal since the clustering variable (cognitive response to food safety concerns) in this study is categorical (Bacher et al., 2002). Second, it eliminates the problems of the cluster algorithms such as k-means clustering and agglomerative hierarchical techniques (Bacher, 2000). Third, the two-step clustering algorithm, combined with the log-likelihood estimation, computes the probability of cluster membership on a probability distribution, hence able to reveal the natural groupings within a dataset that would otherwise not be obvious (Bacher, 2000; Font et al., 2016). In this study, the algorithm was allowed to automatically determine the optimal number of clusters that naturally exist in the data by comparing the values of the model-choice criterion across different clustering solutions.

Next, the Kruskal Wallis rank-sum test for means of several groups was used to determine the cluster characteristics in relation to the respondents' conative response to food safety concerns. Additionally, the Kruskal Wallis test was used to assess the differences in behavioural traits towards the consumption of local food across the clusters (Pallant \& Manual, 2010). In both cases, when the Kruskal Wallis test is used, the Dunn's post hoc pairwise tests with Bonferroni error correction was used to examine the significant differences for test results that were found to be significant. The Kruskal Wallis test is a nonparametric test that allows for the comparison of three or more groups. Unlike other parametric alternatives (ANOVA, MANOVA), it does not assume the normality of the data and works with uneven and small samples. Hence, it is considered appropriate for this kind of analysis as the samples at the cluster level were uneven and small. Finally, the Chi-square test of independence was used to profile the food safety clusters by the sociodemographics of the respondents to further understand the identities of each cluster.

\section{Profile of the Respondents}

Females constitute a little over half of the sample (56.0\%). Respondents in the 21 to 25 years age category are in majority (67.0\%). Meanwhile, most of the students surveyed (56\%) are studying in the humanities and social sciences (Table 3) with close to two-thirds (67.9\%) originating from other African countries. 
Tables 3: Socio-Demographic Profile of Respondents

\begin{tabular}{lll}
\hline Socio-demographic & Frequency & Percent \\
\hline Sex & 61 & 56.0 \\
$\quad$ Male & 48 & 44.0 \\
$\quad$ Female & & \\
Age $^{*}$ (years) & 17 & 15.6 \\
$\quad 76-20$ & 73 & 67.0 \\
$21-25$ & 19 & 17.4 \\
$26-30$ & & \\
Discipline & 61 & 56.0 \\
$\quad$ Humanities & 48 & 44.0 \\
$\quad$ Science & & \\
Continent of origin & 29 & 26.6 \\
$\quad$ Europe & 74 & 67.9 \\
$\quad$ Non-Ghanaian African & 6 & 5.5 \\
$\quad$ Other & & \\
\hline
\end{tabular}

\section{FINDINGS}

\section{Segments of Cognitive Responses on Food Safety Concerns}

Three clusters emerged from the two-step cluster analysis based on the six items on the cognitive responses towards food safety concerns (Table 4). The uniqueness of each cluster is based on the pattern of responses to each of the six elements that make up the cluster compared to the overall response at the sample level. The difference between the cluster and sample percentages formed the basis for the clustering and defines the feature of each cluster. A variable that makes a cluster unique is called a marker variable (Dolnicar \& Leisch, 2013). Dolnicar and Leisch (2013) describe a marker variable as a variable whose absolute deviation from the overall mean is $25 \%$ of the maximum value or if the relative deviation is $50 \%$. Marker variables form the basis for labelling and understanding the make-up of a cluster while non-marker variables offer little insight into a cluster. In this regard, all six cognitive responses towards food safety concerns are marker variables for all three clusters as they are useful in labelling and understanding the characteristics of each of them.

In Cluster 1 , there is a high proportion of agreement to all self-cognitive responses towards food safety concerns but a relatively high disagreement to the cognitive evaluation of others on food safety concerns as compared to the responses at the sample level (Table 4). This indicates that members of this cluster respond to self-cognition regarding food safety concerns but deny the cognition of others on same. For Cluster 2, they have a relatively high proportion of strong agreement on all six cognitive elements compared to the responses at the sample level (Table 4). This suggests that this cluster responds to self-cognition as well as the cognition of others towards food safety concerns. Simply put, members of this cluster have high cognitive responses towards food safety concerns on local foods. However, Cluster 3 has a high proportion of disagreement to all six cognitive items, suggesting that members of this cluster do not respond cognitively towards food safety concerns on local foods. 
Table 4: Segments of Cognitive Responses on Food Safety Concerns

\begin{tabular}{|c|c|c|c|c|c|c|c|c|}
\hline \multirow{2}{*}{$\begin{array}{l}\text { Cognitive } \\
\text { item }\end{array}$} & \multirow{2}{*}{$\begin{array}{l}\text { Cluster } \\
37.6 \%) \\
\text { A }\end{array}$} & \multirow{2}{*}{$\begin{array}{l}1 \quad(n=41 \\
D\end{array}$} & \multirow{2}{*}{$\begin{array}{l}- \text { Cluster } 2(\mathrm{n}=44- \\
40.4 \%) \\
\text { SA }\end{array}$} & \multirow{2}{*}{$\begin{array}{l}\text { Cluster } 3 \quad(\mathrm{n}=\quad 24- \\
22.0 \%) \\
\mathrm{D}\end{array}$} & \multicolumn{4}{|c|}{ Sample $(\mathrm{n}=109)$} \\
\hline & & & & & SD & D & A & SA \\
\hline COG01 & 85.4 & & 52.3 & 70.8 & 4.6 & 27.5 & 44.0 & 23.9 \\
\hline COG02 & 95.1 & & 75.0 & 70.8 & 1.8 & 22.0 & 45.0 & 31.2 \\
\hline COG03 & & 46.3 & 45.5 & 58.3 & 14.7 & 43.1 & 21.1 & 21.1 \\
\hline COG04 & & 48.8 & 47.7 & 79.2 & 11.0 & 40.4 & 28.4 & 20.2 \\
\hline COG05 & 70.7 & & 40.9 & 95.8 & 3.7 & 39.4 & 44.0 & 12.8 \\
\hline COG06 & 82.9 & & 38.6 & 62.5 & 6.4 & 33.0 & 45.0 & 15.6 \\
\hline
\end{tabular}

\section{Affective Responses of Cognitive Segments}

In consonance with the tri-component model guiding this study, cognitive evaluations translate into conative or affective responses such that people with cognition of food safety issues are expected to express it in their conative judgments on local foods. To this end, the three segments of cognitive responses towards local food safety concerns were profiled by the conative evaluations on local food safety concerns using Kruskal Wallis rank sum test with Dunn's post hoc with Bonferroni correction (Table 5).

Cluster 1 has the lowest affective feeling of getting sick from eating local food due to contamination compared to the other two groups but has a higher feeling of concern about how local food is handled and consumed compared to cluster 3, though less than Cluster 2. On the other hand, Cluster 2 has the highest level of affective response regarding how potential contamination of local food could affect them as well as how local food is handled and consumed as compared to the other two segments. Cluster 3 has the lowest feeling of concern on how local food is handled and consumed compared to the other two segments but express greater concern about potential contamination of local food than Cluster 1.

Table 5: Affective Traits of Cognitive Segments on Food Safety Concerns (Kruskal Wallis)

\begin{tabular}{|c|c|c|c|c|c|}
\hline $\begin{array}{l}\text { Conative } \\
\text { item }\end{array}$ & Cluster 1 & $\begin{array}{l}\text { Cluster } \\
2\end{array}$ & Cluster 3 & $\chi^{2}(\varrho)$ & $\begin{array}{l}\text { Dunn's post hoc with Bonferroni } \\
\text { correction }\end{array}$ \\
\hline AFF01 & 33.15 & 76.15 & 54.81 & $12.61(0.002)$ & $\begin{array}{l}\mathrm{C} 1-\mathrm{C} 2=26.76(0.002) \\
\mathrm{C} 2-\mathrm{C} 3=17.67(0.017) \\
\mathrm{C} 1-\mathrm{C} 3=20.32(0.011)\end{array}$ \\
\hline AFF02 & 35.83 & 78.31 & 56.27 & $14.63(0.001)$ & $\begin{array}{l}\mathrm{C} 1-\mathrm{C} 2=-22.48(0.002) \\
\mathrm{C} 2-\mathrm{C} 3=22.04(0.010) \\
\mathrm{C} 1-\mathrm{C} 3=15.44(0.016)\end{array}$ \\
\hline AFF03 & 56.80 & 71.56 & 38.65 & $24.86(0.000)$ & $\begin{array}{l}\mathrm{C} 1-\mathrm{C} 2=-24.75(0.000) \\
\mathrm{C} 2-\mathrm{C} 3=32.91(0.000) \\
\mathrm{C} 1-\mathrm{C} 3=19.16(0.012)\end{array}$ \\
\hline AFF04 & 58.07 & 79.34 & 40.54 & $19.99(0.000)$ & $\begin{array}{l}\mathrm{C} 1-\mathrm{C} 2=-21.27(0.002) \\
\mathrm{C} 2-\mathrm{C} 3=28.79(0.000) \\
\mathrm{C} 1-\mathrm{C} 3=21.53(0.011)\end{array}$ \\
\hline
\end{tabular}




$\begin{array}{rrrr}\text { AFF05 } 58.15 \quad 31.73 \quad 36.04 & 26.80(0.000) & \text { C1-C2 }=-23.58(0.001) \\ & & \text { C2-C3 }=35.69(0.000) \\ & & \text { C1-C3 }=13.11(0.021)\end{array}$

Table 5 Continued

\begin{tabular}{|c|c|c|c|c|c|}
\hline $\begin{array}{l}\text { Conative } \\
\text { item }\end{array}$ & Cluster 1 & $\begin{array}{l}\text { Cluster } \\
2\end{array}$ & Cluster 3 & $\chi^{2}(\varrho)$ & $\begin{array}{l}\text { Dunn's post hoc with Bonferroni } \\
\text { correction }\end{array}$ \\
\hline \multirow[t]{3}{*}{ AFF06 } & 58.45 & 75.64 & 38.15 & $14.28(0.001)$ & $\mathrm{C} 1-\mathrm{C} 2=-12.19(0.022)$ \\
\hline & & & & & $\mathrm{C} 2-\mathrm{C} 3=27.49(0.001)$ \\
\hline & & & & & $\mathrm{C} 1-\mathrm{C} 3=15.31(0.016)$ \\
\hline \multirow[t]{3}{*}{ AFF07 } & 58.72 & 78.33 & 36.17 & $20.09(0.000)$ & $\mathrm{C} 1-\mathrm{C} 2=-16.61(0.015)$ \\
\hline & & & & & $\mathrm{C} 2-\mathrm{C} 3=32.16(0.000)$ \\
\hline & & & & & $\mathrm{C} 1-\mathrm{C} 3=15.55(0.009)$ \\
\hline
\end{tabular}

$\mathrm{C} 1=$ Cluster $1, \mathrm{C} 2=$ Cluster 2, C3 = Cluster 3

\section{Segments of Self-Assured, Pessimists and Epicureans}

According to the tri-component model that underpins this study, socio-psychological responses towards local food safety concerns are threefold, with the starting point being cognitive response which in turn informs how an individual will respond conatively, and ultimately both cognitive and conative responses will influence how the person will behave towards local food (Kanuk \& Schiffman, 2009). Based on this theoretical guidance, the cognitive segments on local food safety concerns are further profiled by the respondents' behavioural responses towards local food (Table 4).

Table 6: Conative Traits of Cognitive Segments on Food Safety Concerns (Kruskal Wallis)

\begin{tabular}{|c|c|c|c|c|c|}
\hline Conative item & Self-regards & Pessimists & Epicureans & $\chi^{2}(\varrho)$ & $\begin{array}{l}\text { Dunn's post hoc with } \\
\text { Bonferroni correction }\end{array}$ \\
\hline \multirow[t]{3}{*}{ CON01 } & 58.98 & 74.22 & 38.40 & $10.65(0.004)$ & $\mathrm{C} 1-\mathrm{C} 2=-21.24(0.001)$ \\
\hline & & & & & $\mathrm{C} 2-\mathrm{C} 3=28.82(0.000)$ \\
\hline & & & & & $\mathrm{C} 1-\mathrm{C} 3=20.58(0.003)$ \\
\hline \multirow[t]{3}{*}{ CONO2 } & 59.59 & 74.15 & 37.48 & $11.28(0.003)$ & $\mathrm{C} 1-\mathrm{C} 2=-24.67(0.002)$ \\
\hline & & & & & $\mathrm{C} 2-\mathrm{C} 3=27.87(0.000)$ \\
\hline & & & & & $\mathrm{C} 1-\mathrm{C} 3=-19.54(0.004)$ \\
\hline \multirow[t]{3}{*}{ CON03 } & 53.20 & 74.84 & 30.04 & $11.65(0.003)$ & $\mathrm{C} 1-\mathrm{C} 2=-24.65(0.000)$ \\
\hline & & & & & $\mathrm{C} 2-\mathrm{C} 3=28.79(0.000)$ \\
\hline & & & & & $\mathrm{C} 1-\mathrm{C} 3=20.15(0.004)$ \\
\hline \multirow[t]{3}{*}{ CONO4 } & 56.60 & 70.83 & 31.58 & $10.20(0.004)$ & $\mathrm{C} 1-\mathrm{C} 2=-21.23(0.001)$ \\
\hline & & & & & $\mathrm{C} 2-\mathrm{C} 3=27.25(0.000)$ \\
\hline & & & & & $\mathrm{C} 1-\mathrm{C} 3=-19.23(0.005)$ \\
\hline \multirow[t]{3}{*}{ CON05 } & 51.05 & 72.16 & 38.63 & $11.81(0.003)$ & $\mathrm{C} 1-\mathrm{C} 2=-22.24(0.000)$ \\
\hline & & & & & $\mathrm{C} 2-\mathrm{C} 3=27.82(0.000)$ \\
\hline & & & & & $\mathrm{C} 1-\mathrm{C} 3=20.58(0.002)$ \\
\hline
\end{tabular}



CON06
56.67
79.16
33.27
$17.26(0.000)$
$\mathrm{C} 1-\mathrm{C} 2=-22.49(0.001)$
$\mathrm{C} 2-\mathrm{C} 3=28.89(0.000)$
$\mathrm{C} 1-\mathrm{C} 3=19.40(0.003)$

Cluster 1 has the second-highest avoidance of local foods after Cluster 2. Juxtaposed with their cognitive and affective responses to local food safety concerns, it is realised that this segment has a high selfcognitive response towards local food safety concerns but does not value the cognitive evaluations of others on the same. This suggests that members of this group are self-centred in their responses towards local food safety concerns and, consistent with this, have a high affective feeling towards local food based on how they see local food being handled and consumed. Consequently, this group is labelled as self-assured as they tend to be focused on their own cognitive and affective evaluations on local food safety concerns but not regard that of others. Cluster 2 easily responds to all kinds of food safety concerns by avoiding local food compared to the two other segments (Table 6).

This conative trait is consistent with their high cognitive responses to local food safety concerns, whether based on self-cognition or the cognition of friends and health experts. Similarly, they express high feelings towards food safety concerns and, thus, can be said to be food sceptics. This is reminiscent of the fact that they highly believe in food safety issues, express profound reservations towards local food based on safety concerns and avoid or are cautious of consuming local food. Hence, they are labelled as pessimists. Cluster 3 has the slowest reaction in avoiding the consumption of local food due to food safety concerns. As shown in Table 6, of all the three segments, this segment differs on all conative items in avoiding the consumption of local food based on food safety concerns, suggesting that they do not avoid local foods based on safety concerns. This conative trait is built on their cognitive disregard for local food safety concerns since they do not believe in food safety issues, as shown in Table 3. Also, they do not express any feelings towards food safety issues. Overall, this segment does not respond to food safety concerns, be it cognitively, affectively, or conatively. They are not perturbed by food safety concerns and will consume local food regardless of such concerns. Therefore, they are named epicureans.

\section{Profile of Cognitive Segments on Food Safety Concerns Across Socio-Demographics}

The three segments of international students' responses towards local food safety concerns were profiled across their socio-demographic characteristics (Table 7). The results show that the three segments are statistically unique in relation to two socio-demographic variables, namely age and continent of origin. Regarding age, most of those aged between 21 to 25 years (45.2\%) are self-assured while most of those aged 16 to 20 years $(47.1 \%)$ and 26 to 30 years $(57.9 \%)$ are pessimists. Meanwhile, there is a higher proportion of those aged between 26 to 30 years who are epicureans than those in other age categories. On the continent of origin, while most of those who originate from the continent of Europe are self-assured (58.6\%), most of their counterparts from other African countries are epicureans $(61.0 \%)$. 
Table 7: Socio-Demographic Profiles of Cognitive Segments (Chi-Square)

\begin{tabular}{lllll}
\hline Socio-demographic & $\begin{array}{l}\text { Self- } \\
\text { assured }\end{array}$ & Pessimist & Epicurean & $\chi^{2}(\varrho)$ \\
\hline Sex & 35.4 & 43.8 & 20.8 & $0.408(0.815)$ \\
$\quad$ Male & 39.3 & 37.7 & 23.0 & \\
$\quad$ Female & & & & $11.55(0.021)$ \\
Age (years) & 41.2 & 47.1 & 11.8 & \\
$\quad$ 16-20 & 45.2 & 34.2 & 20.5 & \\
$21-25$ & 5.3 & 57.9 & 36.8 & \\
$26-30$ & & & & $1.51(0.469)$ \\
Discipline & 42.6 & 37.7 & 19.7 & \\
$\quad$ Humanities & 31.3 & 43.8 & 25.0 & \\
$\quad$ Science & & & & $10.56(0.032)$ \\
Content of origin & 58.6 & 20.7 & 20.7 & \\
$\quad$ Europe & 20.7 & 18.3 & 61.0 & \\
$\quad$ Non-Ghanaian African & 33.3 & 31.8 & 34.9 & \\
$\quad$ Other & & & & \\
\hline
\end{tabular}

\section{DISCUSSION}

While researchers have made attempts to understand the food safety concerns of consumers, these have often been limited to the sensory reactions to the way food is prepared and handled without recourse to an in-depth socio-psychological analysis of consumers' responses to food safety concerns within the context of foreign dishes influence their behaviour towards the consumption of such foods. Meanwhile, evidence from consumer psychology (Chih et al., 2015; Chowdhury \& Salam, 2015) suggests that individuals' concerns and associated decisions to consume foreign products constitute a socio-psychological process especially in the case of food due to its socio-cultural meaning and value (Mullan et al., 2013). In this regard, it is imperative to understand the cognitive responses towards local food safety concerns and how such responses transcend the mental processes into affective responses and consumption behaviour, hence the need and value of this study. The findings of this study reveal that some of the international students in Ghana mentally react to local food safety concerns albeit in varied ways. As revealed in the study, two of the three segments cognitively react to local food safety concerns, thereby suggesting that the expression of food safety concerns is beyond the usual sensory categorizations but involves the mental processing of the food safety encounters which could potentially trigger certain behavioural responses towards the consumption of such food.

Further, this study makes a valuable contribution to the food safety literature by employing cluster analysis to produce different shades of sociopsychological reactions to local food safety concerns. This is a departure from previous studies (ByrdBredbenner et al., 2010; Ferk et al., 2016; Luo et al., 2019; Osaili et al., 2011) that have relied on just sensory reactions and categorisations of consumers towards food safety concerns. Specifically, this study reveals that international consumers of local food are not homogeneous but heterogeneous in their cognitive, conative, and affective responses towards local food safety conditions. The findings revealed that there are two extremes and those in the middle. One extreme has strong cognitive reactions towards local food safety concerns with equally high affective concerns and 
ultimately avoiding the consumption of local food and therefore named as pessimists. The pessimists are characterised by high cognitive sensitivities towards local food safety concerns and, therefore, cognitively respond to both self-cognition and the cognition of others on local food safety concerns, especially those from experts and significant others. This might be because of information overload, lacking proof for food safety and feelings of powerlessness (Simons, 2010), and trust in food production and regulations (Eden et al., 2008). Consequently, this creates doubts in their minds as to whether local foods are safe to consume or otherwise and, therefore, tend to be sceptical about the safety conditions of local foods. The cognitive scepticism reflects in their expression of reservations regarding the safety of local food. Here, they openly express their doubt and tend to demonstrate this doubt and fear of the worse happening by avoiding the consumption of local foods. Therefore, this segment's profile is underpinned by their doubt on the safety of local food and, therefore, are careful and not entirely convinced of the outcome of consuming local food.

The other extreme segment and the direct opposite of the pessimists are the epicureans. The epicureans disregard cognitive concerns on local food safety concerns, express less affective concerns and eventually consume local foods regardless of the food safety concerns. Curiosity might be the most important reason for this action (Sogari et al., 2017). This segment is not perturbed by the fact that they are encountering exotic food, prepared, and handled in ways that are different from what they are used to, and therefore represent source(s) of food safety concerns. They simply do not engage in any cognitive evaluations of the local food safety conditions. Similarly, they do not express any expressive feeling about local food safety conditions, cap this with the behaviour of non-avoidance of local food and, hence, consume local foods. This segment is food adventurers (Menozzi et al., 2017; Sogari et al., 2019) and devoted to enjoying themselves through the consumption of local food, hence the label epicureans. Essentially, their attitude towards local food safety concerns is reminiscent of that underpinned by epicureanism which argues that pleasure is the main commodity of life and that one must live in a way that allows him/her to derive the greatest pleasure of life at any moment and through any means including the consumption exotic food (Roskam, 2007). Critically, epicureanism advocates a simple life and the fact that the absence of fear and pain is the greatest source of pleasure (Roskam, 2007), thereby allowing one to continuously live the moment as in the case of this segment who refuse to bother themselves with potential food safety concerns.

The third segment is midway between the two extremes. Members of this segment are only sensitive to their self-cognitive responses towards local food safety concerns but deny the cognitive evaluation of experts, friends, and family towards same. In this regard, they only believe in their own socio-psychological evaluation of local food safety concerns. Regarding their concerns on food safety, they are self-centred (Dambrun \& Ricard, 2011) such that they believe they know and only trust their own judgements based on what they see and experience. Reiterating Schafer et al.'s (1993) assertion that individuals who feel a personal threat and believe they can do something about it are more likely to engage in food safety behaviour. Therefore, they have relatively high affective concerns compared to the pessimists but lower than that of the epicureans. Similarly, their avoidance of local food is not as strong as that of the epicureans but profound than that of the pessimists. However, their avoidance of local food is based on their self-centred cognitive evaluations of the local food 
safety conditions based on how they witness local food being prepared and handled. Their cognitive evaluation of local food safety conditions as well as their behaviour towards local food is based on their immediate selfcentred evaluations and the fact that it is only their own mental evaluations that can help them adequately protect their self-interest. They are, therefore, labelled as selfassured.

\section{CONCLUSIONS AND IMPLICATIONS}

This study sought to understand the cognitive, affective, and conative responses towards local food safety concerns amongst international students in Ghana. Consequently, the findings revealed that there are shades of international students' cognitive, affective, and conative responses towards local food safety conditions in Ghana. One segment named pessimists have high cognitive and affective responses towards local food safety conditions and as such, avoid the consumption of local foods. Another segment called epicureans do not respond cognitively and affectively towards local food safety conditions and, therefore, do not avoid but consume local food with little hesitations while the third group, self-assureds, are only concerned with their own cognitive evaluations of local food safety situations but not that of others and subsequently consume local food but not as much as the epicureans. Based on these findings, the following conclusions are drawn.

This paper concludes that concerns on local food safety conditions are a socio-psychological process and not merely a sensory exercise limited to what is seen. In other words, concerns expressed towards local food safety situations in international contexts are based on the mental processes involved in synthesising what is believed to be ideal against what is presented or seen. This mental cognitive processing of local food safety concerns triggers other affective and conative responses towards such local foods. This, therefore, implies that the preparation and handling of local foods need to be done in accordance with well-established universal food safety protocols. This will ensure that it is not significantly different from what international visitors are used to and, thereby, reduce the cognitive dissonance by way of overly sensitive cognitive responses that may trigger similar affective responses that will result in the avoidance of the consumption of local food, especially amongst the pessimists and the self-assureds. Relatedly, local authorities such as the local assemblies and food regulatory bodies can also train the local foodservice providers on such well-established universal food safety protocols to enable them to implement them in the preparation, handling, and presentation of food items to distort the high cognitive dissonance related to local food safety concerns.

Further, the study concludes that there are three segments of international student consumers of local food based on their food safety concerns in Ghana. As revealed in the findings, the pessimists have high cognitive sensitivities towards local food safety conditions and openly express this by way of their affective responses and avoiding the consumption of local foods. On the other hand, the epicureans do not cognitively and affectively respond to local food safety conditions and, therefore, patronize local food regardless of the safety situations, with the self-assureds only considering their own self-cognition in dealing with local food safety conditions and, to some extent, consumption of local foods. These three segments present clarity on how international students behave towards local food based on their food safety concerns and, therefore, have implications for the packaging and marketing of local foods to international visitors. For instance, both the self-assureds and the pessimists can 
be targeted with well labelled and branded local food items as well as planned and regulated formal eateries that are certified to be safe and of high quality. These will help to reduce the high cognitive concerns on local food safety conditions. Also, the pessimists can be targeted with marketing messages and brand ambassadors who will guarantee the safety of local foods since they have high regard for the cognitive evaluation of others on food safety issues.

\section{REFERENCES}

Abbot, J. M., Byrd-Bredbenner, C., Schaffner, D., Bruhn, C. M., \& Blalock, L. (2009). Comparison of food safety cognitions and self-reported foodhandling behaviours with observed food safety behaviours of young adults. European Journal of Clinical Nutrition, 63, 572-579.

Adam, I., Hiamey, S. E, \& Afenyo, E. A. (2014). Students' food safety concerns and choice of eating place in Ghana. Food Control, 43, 135141.

Adesokan, H.K., Akinseye, V. O., \& Adesokan, G. A. (2015). Food safety training is associated with improved knowledge and behaviours among foodservice establishments' workers. International Journal of Food Science, 2015, 18.

Adeyeye, S. A. O. (2016). Fungal mycotoxins in foods: A review. Cogent Food \& Agriculture, 2(1), 111.

Alakaam, A. A., Castellanos, D. C., Bodzio, J., \& Harrison, L. (2015). The factors that influence dietary habits among international students in the United States. Journal of International Students, 5(2), 201-218.

Almohanna, M. S., Barbeau, W., Conforti, F., \& Eigel, W. (2015). Impact of dietary acculturation on the food habits, weight, blood pressure, and fasting blood glucose levels of international college students. Journal of American College Health, 63(5), 307-314.

Amuquandoh, F. E. \& Asafo-Adjei, R. (2013). Traditional food preferences of tourism in Ghana. British Food Journal, 115, 987-1002.

Assael, H. (2004). Consumer behaviour: A strategic approach. Boston: Houghton Mifflin Company.

Bacher, J. A. (2000). Probabilistic clustering model for variables of mixed type. Quality \& Quantity, 34, 223-235.

Bacher, J., Brand, R., \& Bender, S. (2002). Reidentifying register data by survey data using cluster analysis: An empirical study. International Journal of Uncertainty, Fuzziness and Knowledge-Based Systems, 10(5), 589-608.

Bansah, A. K., Moore, D. R., \& Holben, D. H. (2018). The effect of message emotion and logic on nutritional attitude change as measured by argumentation style in an online nutrition class. Topics in Clinical Nutrition, 33(4), 281-292.

Braziotis, C., Bourlakis, M., Rogers, H., \& Tannock, J. (2013). Supply chains and supply networks: Distinctions and overlaps. Supply Chain Management: An International Journal, 18(6), 644-652.

Brewer, M. S. \& Rojas, M. (2008). Consumer attitudes toward issues in food safety. Journal of Food Safety, 28, 1-22.

Byrd-Bredbenner, C., Abbot, J. M., \& Quick, V. (2010). Food safety knowledge and beliefs of middle school children: Implications for food safety educators. Journal of Food Science Education, 9(1), 19-30.

Byrd-Bredbenner, C., Abbot, J. M., Wheatley, V., Schaffner, D., Bruhn, C., \& Blalock, L. (2008). 
Risky eating behaviours of young adultsimplications for food safety education. Journal of the American Dietetic Association, 108(3), 549552.

Byrd-Bredbenner, C., Maurer, J., Wheatley, V., Schaffner, D., Bruhn, C., \& Blalock, L. (2007). Food safety self-reported behaviours and cognitions of young adults: Results of a national study. Journal of Food Protection, 70, 19171926.

Cacciolatti, L. A., Garcia, C. C., \& Kalantzakis, M. (2015). Traditional food products: The effect of consumers' characteristics, product knowledge, and perceived value on actual purchase. Journal of International Food \& Agribusiness Marketing, 27(3), 155-176.

Caraher, M., Baker, H., \& Burns, M. (2004). Children's views of cooking and food preparation. British Food Journal, 106(4), 255-273.

Ceylan, Z., Meral, R., Cetinkaya, T. (2020). Relevance of SARS-CoV-2 in food safety and food hygiene: Potential preventive measures, suggestions and nanotechnological approaches. Virus Disease 31, 154-160.

Cheng, Y., Zhang, Y., Ma, J., \& Zhan, S. (2017). Food safety knowledge, attitude, and self-reported practice of secondary school students in Beijing, China: A cross-sectional study. PLoS One, 12(11), 0187208 .

Chih, W. H., Liou, D. K., \& Hsu, L.C. (2015). From positive and negative cognition perspectives to explore e-shoppers' real purchase behavior: An application of tricomponent attitude model. Information Systems and e-Business Management, 13(3), 495-526.

Chowdhury, S. K. \& Salam, M. (2015). Predicting attitude based on cognitive, affective, and conative components: An online shopping perspective. Stamford Journal of Business Studies, 6/7(II/I), 101-115.

Clayton, D. A., Griffith, C. J., \& Price, P. (2003). An investigation of the factors underlying consumers' implementation of specific food safety practices. British Food Journal, 105(7), 434-453.

Corcoran, N. (2018). Exploring international students' food choices using photovoice techniques. Journal of International Students, 8(1), 175-193.

Cortese, R. D. M., Veiros, M. B., Feldman, C., \& Cavalli, S. B. (2016). Food safety and hygiene practices of vendors during the chain of street food production in Florianopolis, Brazil: A crosssectional study. Food Control, 62, 178-186.

Coulson, N. S. (2002). Source of food safety information: whom do adolescents trust? Appetite, 38, 199-200.

Cronbach, L. J. (1951). Coefficient alpha and the internal structure tests. Psychometrika, 16(3), 297-334.

Dambrun, M. \& Ricard, M. (2011). Self-centeredness and selflessness: A theory of self-based psychological functioning and its consequences for happiness. Review of General Psychology, 15(2), $138-157$.

Desmet, P. M. \& Schifferstein, H. N. (2008). Sources of positive and negative emotions in food experience. Appetite, 50(2), 290-301.

Doherty, B., Smith, A., \& Parker, S. (2015). Fair trade market creation and marketing in the Global South. Geoforum, 67(67), 158-171.

Dolnicar, S. \& Leisch, F. (2013). Using graphical statistics to better understand market segmentation solutions. International Journal of Market Research, 56(2), 97-120. 
Du Plooy, Z., Schönfeldt, H. C., \& Hall, N. (2018). The role of traditional foods in food-based dietary guidelines-A South African case study on maas (cultured milk). Food Chemistry, 238, 22-28.

Eden, S., Bear, C., \& Walker, G. (2008). The sceptical con sumer? Exploring views about food assurance. Food Policy, 33, 624-3.

Eriksen, S. N. (2013). Defining local food: Constructing a new taxonomy: Three domains of proximity. Acta Agriculturae Scandinavica, Section B Soil and Plant Science, 63(1), 47-55.

Eves, A., Bielby, G., Egan, B., Lumbers, M., Raats, M., \& Adams, M. (2006). Food hygiene knowledge and self-reported behaviours of UK school children (4-14years). British Food Journal, 108, 706-720.

Feldmann, C. \& Hamm, U. (2015). Consumers' perceptions and preferences for local food: A review. Food Quality and Preference, 40, 152164.

Ferk, C. C., Calder, B. L., \& Camire, M. E. (2016). Assessing the food safety knowledge of University of Maine students. Journal of Food Science Education, 15(1), 14-22.

Font, X., Garay, L., \& Jones, S. (2016). A social cognitive theory of sustainability empathy. Annals of Tourism Research, 58, 65-80.

Giritlioglu, I., Batman, O., \& Tetik, N. (2011). The knowledge and practice of food safety and hygiene of cookery students in Turkey. Food Control, 22(6), 838-842.

Girma, S., \& Hanley, A. (2015). How Green are Exporters? Scottish Journal of Political Economy, 62(3), 291-309.

Gizaw, Z., Gebrehiwot, M., \& Teka Z. (2014). Food safety practice and associated factors of food handlers working in substandard food establishments in Gondar Town, Northwest Ethiopia. International Journal of Food Science Nutrition and Diet, 3(7), 138-146.

Green, E. J., \& Knechtges, P. L. (2015). Food safety knowledge and practices of young adults. Journal of Environmental Health, 77(10), 18.

Guerrero, L., Claret, A., Verbeke, W., Sulmont-Rossé, C., \& Hersleth, M. (2016). Innovation in traditional food products: Does it make sense? In C. M. Galanakis (Ed.), Innovation strategies in the food industry (pp. 77-89). Elsevier.

Guerrero, L., Guardia, M. D., Xicola, J., Verbeke, W., Vanhonacker, F., Zakowska-Biemans, S., Sajdakowska, M., Sulmont-Rosse, C., Issanchou, S., Contel, M., Scalvedi, L M., Granli, S. B., \& Hersleth, M. (2009). Consumer-driven definition of traditional food products and innovation in traditional foods. A qualitative cross-cultural study. Appetite, 52(2), 345-354

Ha, T. M., Shakur, S., \& Pham Do, K. H. (2018). Consumer concern about food safety in Hanoi,Vietnam. Food Control, 98, 238-244.

Harris, K., \& Mullan, B. (2009). Extending the theory of planned behaviour: the role of habit, anticipated regret, and knowledge in food hygiene behaviour. In the Australasian Society of Behavioural Health and Medicine (ASBHM) 7th annual scientific conference, Brisbane, Australia.

Hassan, H. F. \& Dimassi, H. (2014). Food safety and handling knowledge and practices of Lebanese university students. Food Control, 40(2), 127133.

Hertzman, J. L., Kitterlin, M., Farrish, J., \& Stefanelli, J. (2011). The effect of food safety education and work experience on knowledge, attitudes, and practices of university students. Journal of Hospitality \& Tourism Education, 23(1), 18-27. 
Hiamey, S. E. \& Hiamey, G. A. (2018). Street food consumption in a Ghanaian metropolis: The concerns determining consumption and nonconsumption. Food Control, 92, 121-127.

Hidalgo-Milpa, M., Arriaga-Jordán, C. M., CesínVargas, A., \& Espinoza-Ortega, A. (2016). Characterisation of consumers of traditional foods: The case of Mexican fresh cheeses. British Food Journal, 118(4), 915-930

Hovsepyan, R., Stepanyan-Gandilyan, N., Melkumyan, H., \& Harutyunyan, L. (2016). Food as a marker for economy and part of identity: Traditional vegetal food of Yezidis and Kurds in Armenia. Journal of Ethnic Foods, 39(1), 32-41.

Hsu, F. C., Robinson, R. N. S., \& Scott, N. (2018). Traditional food consumption behaviour: The case of Taiwan. Tourism Recreation Research 43, 456-469.

Lazou, T., Georgiadis, M., Pentieva, K., Mckevitt, A., \& Iossifidou, E. (2012). Food safety knowledge and food-handling practices of Greek university students: A questionnaire- based survey. Food Control, 28(2), 400-411.

Liu, A., \& Niyongira, R. (2017). Chinese consumers food purchasing behaviours and awareness of food safety. Food Control, 79(9), 185-191.

Luo, X., Xua, X., Chen, H., Bai, R., Zhang, Y., Hou, X., Zhang, F., Zhang, Y., Sharma, M., Zeng, H., \& Zhao, Y. (2019). Food safety related knowledge, attitudes, and practices (KAP) among the students from nursing, education and medical college in Chongqing, China. Food Control, 95, $181-188$.

Maio, G. R. \& Haddock, G. (2009). The psychology of attitudes and attitude change. Sage.

Makanyeza, C. (2014). Measuring consumer attitude towards imported poultry meat products in a developing market: An assessment of reliability, validity, and dimensionality of the tri-component attitude model. Mediterranean Journal of Social Sciences, 5(20), 874.

Menozzi, D. Sogari, G. Veneziani, M. Simoni, E. \& Mora, C. (2017). Eating novel foods: An application of the theory of planned behaviour to predict the consumption of an insect-based product. Food Quality and Preference 59, 27-34.

Mgonja, J. T., Backman, F. K., Backman, J. S., Moore, D. D., \& Hallo, C. J. (2017). A structural model to assess international visitors' perceptions about local foods in Tanzania. Journal of Sustainable Tourism, 25(6), 796-816.

Milazzo, A., Giles, L. C., Zhang, Y., Koehler, A. P., Hiller, J. E., \& Bi, P. (2017). Factors influencing knowledge, food safety practices and food preferences during warm weather of salmonella and campylobacter cases in South Australia. Foodborne Pathogens and Disease, 14(3), 125131.

Mullan, B. A., Wong, C., \& Kothe, E. J. (2013). Predicting adolescents' safe food handling using an extended theory of planned behaviour. Food Control, 31, 454-460.

Nardi, V. A. M., Teixeira, R., Ladeira, W., \& Santini, F. (2020). A meta-analytic review of food safety risk perception. Food Control. 112, 107089

Nummedal, M., \& Hall, M. (2006). Local food and tourism: An investigation of the New Zealand South Island's bed and breakfast section's use and perception of local food. Tourism Review International, 9, 365-378.

Ohiokpehai, O. (2003). Promoting the nutritional goodness of traditional food products. Pakistan Journal of Nutrition, 2(4), 267-270. 
Okonko, I. O., Adejoye, O. D., Ogun, A. A., Ogunjobi, A. A., Nkang, A. O., \& Adebayo-Tayo, B. C. (2009). Hazard analysis critical control points (HACCP) and microbiology qualities of seafoods as affected by handler's hygiene in Ibadan and Lagos, Nigeria. African Journal of Food Science, 3(2), 011-022.

Omari, R., \& Frempong, G. (2016). Food safety concerns of fast food consumers in urban Ghana. Appetite, 98, 49-54.

Omari, R., Frempong, G. K., \& Arthur, W. (2018). Public perceptions and worry about food safety hazards and risks in Ghana. Food Control, 93, 76-82.

Osaili, T. M, Al-Nabulsi, A. A., \& Krasneh, H.D. (2018). Food safety knowledge among foodservice staff at the universities in Jordan. Food Control, 89, 167-176.

Osaili, T. M., Obeidat, B. A., Abu Jamous, D. O., \& Bawadi, H. A. (2011). Food safety knowledge and practices among college female students in north of Jordan. Food Control, 22(2), 269-276.

Ovca, A., Jevšnik, M., \& Raspor, P. (2014). Food safety awareness, knowledge and practices among students in Slovenia. Food Control, 42, 144151.

Pallant, J. \& Manual, S. S. (2010). A Step by Step Guide to Data Analysis Using SPSS. McGraw-Hill Education.

Penney, U. \& Prior, C. (2014). Exploring the urban consumer's perception of local food. International Journal of Retail \& Distribution Management, 42(7), 580-594.

Pérez-Villarreal, H. H., Martínez-Ruiz, M. P., \& Izquierdo-Yusta, A. (2019). Testing model of purchase intention for fast food in Mexico: How do consumers react to food values, positive anticipated emotions, attitude toward the brand, and attitude toward eating hamburgers? Foods, $8(9), 369$.

Perner, 1. (2018). Attitudes. Retrieved on 8th August 2020 from https://www.consumerpsychologist.com/cb Atti tudes.html.

Ping, H., Huang, W., Bai, R., Fan, Z., Manoj, S., Shi, Z., et al. (2016). Knowledge, attitude, and behaviours related to eating out among university students in China. International Journal of Environmental Research and Public Health, $13(7), 696$.

Rahman, M. M., Mosaddik, A., \& Alam, A. K. (2021). Traditional foods with their constituent antiviral and immune system modulating properties. Heliyon, 7(1), e05957

Roskam, G. (2007). Live unnoticed: On the vicissitudes of an Epicurean doctrine. Brill.

Sahney, S. (2018). Consumer behaviour. Retrieved on $8^{\text {th }} \quad$ August $\quad 2020 \quad$ from https://nptel.ac.in/courses/110105029/pdf\%20sa hany/Module.6-27.pdf

Sanlier, N., \& Konaklioglu, E. (2012). Food safety knowledge, attitude, and food handling practices of students. British Food Journal, 114(4), 469480 .

Savelli, E., Murmura, F., Liberatore, L, Casolani N., \& Bravi, L. (2019). Consumer attitude and behaviour towards food quality among the young ones: Empirical evidence from a survey. Total Quality Management \& Business Excellence, 30(1-2), 169-183.

Schafer, B. R., Schafer, E., Bultena, L. G., \& Hoiberg, O. E. (1993). Food safety: An application of the health belief model. Journal of Nutrition Education, 25(1), 17-24. 
Schiffman, L. G. \& Kanuk, L. L. (2004). Consumer behaviour (8th ed.). Pearson Prentice Hall.

Serrano-Cruz, M., Espinoza-Ortega, A., Sepulveda, W., Vizcarra-Bordi, I., \& Thomé-Ortiz, H. (2018). Factors associated with the consumption of traditional foods in Central Mexico. British Food Journal, 120(11), 2695-2709.

Sharif, M. S. M., Zahari, M. S. M., Nor, N. M., \& Muhammad, R. (2016). The importance of knowledge transmission and its relation towards the Malay traditional food practice continuity. Procedia-Social and Behavioural Science, 222, $567-577$.

Sheth, J. N. \& Mittal, B. (2004). Customer behaviour: A managerial perspective (2nd ed). Mason, Ohio: Thomson - Southwestern.

Simons, J. (2010). Healthy scepticism or blind fear? Food safety from a consumer perspective. Aktuelle Ernährungs medizin, 35(1), s2-s6.

Skalkos, D., Kosma, S. I., Chasioti, E., Skendi, A., Papageorgiou, M., \& Guiné, P. F. R. (2021). Consumers' attitude and perception toward traditional foods of Northwest Greece during the COVID-19 pandemic. Applied Science, 11, 4080.

Smigic, N., Djekic I, Martins, M. L., Rocha, A., Sidiropoulou, N., \& Kalogianni, E. P. (2016). The level of food safety knowledge in food establishments in three European countries. Food Control, 63,187-194.

Sogari, G., Menozzi, D, \& Mora, C. (2019). The food neophobia scale and young adults' intention to eat insect products. International Journal of Consumer Studies, 43, 68-76.

Sogari, G., Menozzi, D., \& Mora, C. (2017). Exploring young foodies' knowledge and attitude regarding entomophagy: A qualitative study in Italy.
International Journal of Gastronomy and Food Science, 7, 16-19.

Soon, J. M., Baines, R., \& Seaman, P. (2012). Metaanalysis of food safety training on hand hygiene knowledge and attitudes among food handlers. Journal of Food Protection, 75(4), 793-804.

Stolzenbach, S., Bredie, W. L. P., \& Byrne, D.V. (2013). Consumer concepts in new product development of local foods: Traditional versus novel honeys. Food Research International, 52(1), 144-152.

Stratev, D., Odeyemi, O. A., Pavlov, A., Kyuchukova, R., Fatehi, F., \& Bamidele, F. A. (2017). Food safety knowledge and hygiene practices among veterinary medicine students at Trakia University, Bulgaria. Journal of Infection \& Public Health, 10(6), 778.

Sun, J., Bo, Y., Shi, J., Wang, P., Zhang, J., Shi, B., et al. (2014). Evaluation of a food safety education on knowledge, attitude, and practice among college students of Henan province, China. Journal of Food \& Nutrition Research, 2(4), $136-140$.

Tanuwidjaja, G., Wiyono, A. E., Wibowo, A., Gerry, G., Shinata, L. M., \& Raynaldo, R. (2016). Redesigning the traditional food kiosk based on local knowledge, case study: Siwalankerto district. Procedia. Social and Behavioral Sciences, 227(227), 560-567.

Trichopoulou, A., Soukara, S., \& Vasilopoulou, E. (2007). Traditional foods: a science and

Vainio, A., Kaskela, J., Finell, E., Ollila, S., \& Lunden, J. (2020). Consumer perceptions raised by the food safety inspection report: Does the smiley communicate a food safety risk? Food Control, 110, 106976. 
Wardle, J., Parmenter, K., \& Waller, J. (2002). Nutrition knowledge and food intake. Appetite, 34, 269275.

World Health Organization. (2017, April 14). Food safety. $\quad$ https://www.who.int/news-room/factsheets/detail/food-safety.

Wu, L., Wang, S., Zhu, D., Hu, W. \& Wang, H. (2015). Chinese consumers' preferences and willingness to pay for traceable food quality and safety attributes: The case of pork. China Economic Review, 35(35), 121-136.

Yulia, C., Hasbullah, H., Nikmawati, E. E., Mubaroq, S. R. Abdullah, C. U., \& Widiaty, I. (2018). Augmented reality of traditional food for nutrition education. MATEC Web Conf. 197, 2-5 